\title{
Polygon-based Landslide Inventory for Bandung Basin Using Google Earth
}

\author{
Sukristiyanti ${ }^{1,2}$, Ketut Wikantika ${ }^{1,3}$, Imam A. Sadisun ${ }^{4}$, Lissa F. Yayusman ${ }^{3}$, and Jevon A. Telaumbanua ${ }^{4}$ \\ ${ }^{1}$ Remote Sensing and GIS Research Group, Faculty of Earth Sciences and Technology, Bandung Institute of Technology (ITB), \\ Indonesia \\ ${ }^{2}$ Research Centre for Geotechnology, Indonesian Institute of Sciences (LIPI), Indonesia \\ ${ }^{3}$ Center for Remote Sensing, Bandung Institute of Technology (ITB), Indonesia \\ ${ }^{4}$ Applied Geology Research Group, Faculty of Earth Sciences and Technology, Bandung Institute of Technology (ITB), Indonesia
}

Received: $2020-10-05$

Accepted: 2021-07-30

Keywords:

landslide inventory,

Google Earth,

polygon-based landslide, Bandung Basin

Correspondent email: sukris.tiyanti@gmail.com

\begin{abstract}
A landslide inventory representing landslide locations is used as a key factor in landslide susceptibility assessment. This paper explores Google Earth (GE) for generating a polygon-based landslide inventory in Bandung Basin. How far GE can identify landslides and their boundaries, source areas, and types were discussed here. Visual interpretation of GE images supported by path tool in GE, official landslide reports, previous research papers, and media was performed. The result is a polygon-based landslide inventory consisting of 194 landslide areas and 194 landslide source areas during 1993-2020. The limitations of GE in preparing the landslide inventory are (1) not covering the timing of the landslide occurrences, (2) tricky to identify small landslides $\left(<100 \mathrm{~m}^{2}\right)$ in anthropogenically transformed areas, and (3) not able to distinguish between earth and debris of landslide material.
\end{abstract}

\section{Introduction}

Landslides are the movement of a mass of rock, debris, or earth down a slope, a definition agreed upon by landslide researchers worldwide (Sassa, 2007). Some landslides are triggered by human activities, e.g., road and railroad constructions, building construction, mining, and other development (Sassa, 2007). Landslide disasters occurred in many areas, especially in mountainous regions, that cause a lot of economic loss and casualties (Sadisun et al., 2006). Many landslide studies are performed to mitigate the disaster; one is preparing zoning maps of landslide-prone areas, termed landslide susceptibility mapping (LSM). Other terms, namely landslide hazard mapping, are used in some studies with the same definition (Anbalagan, 1992; Mora \& Vahrson, 1994). Contrary to (Guzzetti et al., 1999), landslide hazard mapping distinguished landslide susceptibility one. Guzzetti et al. (1999) stated that landslide hazard mapping is more complex since it involves spatial concepts and the concepts of magnitude and time. The further analysis on such landslide studies is landslide risk assessment which uses LSM as an input (Roccati et al., 2021; van Westen et al., 2006; Wang et al., 2021). LSM is generated by using some geoenvironmental factors related to landslides, such as lithology, slope, elevation, land-use, distance to rivers, etc. (Anbalagan, 1992; Cepeda et al., 2010), while landside risk assessment needs socio-economic information, like exposed population and properties (Cepeda et al., 2010; Roslee et al., 2017).

In the landslide susceptibility mapping (LSM) based on the landslide probability, landslide inventory, a collection of historical landslide data, is a primary factor (Lee \& Talib, 2005; Wang et al., 2021). In the landslide probabilistic models, either by using conventional statistic or machine learning-based methods, landslide causative factors and landslide inventory are employed as independent and dependent factors, respectively. In modeling, the old saying of 'garbage in - garbage out' is accurate; therefore, the acquisition of each input data should be appropriately made (Chen et al., 2017). As a dependent factor for landslide susceptibility, landslide location accuracy is crucial Dou et al., 2015; $\mathrm{Xu}, 2015$. It determines the future landslides geoenvironment since it assumes that the future landslides will happen under similar conditions as the past landslides (Lee \& Talib, 2005).

Studies on the landslide inventory are attractive for many researchers, evidenced by many studies concerning building the best technique of semi-automatic (Cao et al., 2016; Li et al., 2016) and automatic landslide extractions on remote sensing imageries (Dou et al., 2015; Keyport et al., 2018; Moosavi et al., 2014; Yu \& Chen, 2017). However, no competent proposed method can replace the visual interpretation, either pixel-based or object-based. The methods encounter some obstacles, for instance (1) spectral differences between landslide objects with other objects, e.g., building, road, bare areas, similar (Cao et al., 2016; Dou et al., 2015), (2) the object-based classification requires knowledge of the mechanisms that cause landslides (Cao et al., 2016), (3) bi-temporal images for change detection, not easy to obtain, (Yu \& Chen, 2017), and is even expensive for high-resolution images, and (4) the proposed method is less accurate if applied in other areas (Yu \& Chen, 2017). The weakness of the proposed methods is misclassification which frequently 
occurs, e.g., false positive (Dou et al., 2015; Keyport et al., 2018) and the inability to detect landslides in shadow areas (Keyport et al., 2018). False positives happened when a particular object was identified as landslides, but it was not (Keyport et al., 2018); it caused overdetection (Li et al., 2016). This condition happens mainly in agricultural (Cao et al., 2016; Keyport et al., 2018) and urban areas. It was hard to distinguish landslide objects from vacant areas, a condition when farmland is unvegetated. Regarding the urban areas, identification difficulties occur because the roofs and roads have a bright appearance, similar to landslide objects (Cao et al., 2016; Keyport et al., 2018). Hence, most landslide susceptibility studies use visual interpretation for preparing the landslide inventory. This article aims to discuss how to prepare the landslide inventory using visual interpretation of the images, which is still rarely deliberated in the previous ones.

Google Earth (GE) supported by historical high spatial resolution images can benefit this effort since the price of those such images is often unaffordable, but it is accessible in GE. A preceding research paper said that GE could not identify landslides for anthropogenically transformed areas; it is only effective for natural protected areas (Rabby \& Li, 2019). In addition, historical landslides were represented by point features (Rabby \& Li, 2019) that are not as accurate as polygon features. Polygon features can describe the size of landslide occurrences better than if they were presented as points.

Most landslide susceptibility assessments used point features (Hong et al., 2019; Kalantar et al., 2018; Liu \& Duan, 2018; Mallick et al., 2018; Pham et al., 2018; Riaz et al., 2018; Zhang et al., 2019; Zhu et al., 2018) and the rests used polygons to represent landslide locations (Juliev et al., 2019; Kavzoglu et al., 2019; Othman et al., 2018; Shirani et al., 2018; Tian et al., 2019). Researchers identified the landslide source area from the whole landslide area (Marjanovic, 2013; Schlögel et al., 2018). They concluded that the source area was preferred since it can represent the failure of a landslide, a location that experiences movement (Hungr et al., 2014), which has a close relationship with the landslide susceptibility (Marjanovic, 2013; Schlögel et al., 2018). Therefore, this research explores using GE to produce a polygon-based landslide inventory consisting of landslide areas and landslide source areas for Bandung Basin. However, this does not cover the timing of the landslide occurrences. The availability of time-series data is limited, and the return period for all images is not uniform worldwide and in the study area.

\section{Methods}

This research was carried out in Bandung Basin (2,307 $\left.\mathrm{km}^{2}\right)$, located in West Java, Indonesia $\left(107.26^{\circ}-107.95^{\circ} \mathrm{E}\right.$ dan $6.73^{\circ}-7.24^{\circ} \mathrm{S}$ ). Hilly and mountainous areas dominate the study area with an altitude of 333-2730 meters above sea level. The slope varies from gentle to steep and belongs to the Bandung Volcanic-Depression Physiographic zone (Kartiko et al., 2006). The frequency of landslides in the study area, calculated by DIBI (Indonesian Disaster Database) http:// dibi.bnpb.go.id/, from $1999-2021$ is 315 . The landslides caused 308 fatalities, 22 people missing, 193 people injured, 620 houses destroyed, and 401 houses damaged. This calculation is the total frequencies and their impact on the four central districts in the Bandung Basin, namely Bandung
City, Cimahi City, Bandung Regency, and West Bandung Regency. Bandung City and Cimahi City areas are included in Bandung Basin, except for Bandung District and West Bandung District. Some areas in the southern and southwest parts of Bandung District are outside Bandung Basin. Likewise, the western part of the West Bandung District is also not in Bandung Basin. In addition, the area in the northeastern part of the Bandung Basin, which is $5.6 \%$, is included in Sumedang Regency.

Landslides are spread in hilly to mountainous areas, and several locations in this study area are oftentimes experiencing landslides, including Pangalengan, Ciwidey, Cililin, Cipatat, and Lembang (Figure 1). The landslide distribution map (Figure 1) results from plotting landslide data from December 19, 2013, to April 1, 2020, from PVMBG (The Center for Volcanology and Geological Hazard Mitigation). In the study area, a devastating landslide occurred in Leuwigajah - Cimahi, a waste landslide in a dumpsite on February 21, 2005, that killed 143 people buried 71 houses (Lavigne et al., 2014). Another devastating landslide occurred in Margamukti Village - Pangalengan Bandung Regency, a landslide on May 5, 2015, that hit a 300 $\mathrm{m}$ long geothermal gas pipeline of Wayang Windu (Yuhendar et al., 2016), and resulting in nine people deaths, two people missing, ten people injured (Rahardjo et al., 2017), and 54 families displaced (Tukino, 2021) (Figure 1).

The main data in this study are historical high spatial resolution images of Google Earth (GE) from 1993 to 2020. The terrain of those images is represented using the Digital Elevation Model (DEM), e.g., Shuttle Radar Topographic Mission (SRTM) which has a spatial resolution of $30 \mathrm{~m}$ or 90 $\mathrm{m}$. As supporting data, official historical landslide reports sourced from the Center for Volcanology and Geological Hazard Mitigation (vsi.esdm.go.id), the previous scientific papers, and media were used.

Four steps were performed to produce landslide inventory by using GE imageries for Bandung Basin. Those steps include (1) identifying landslides both in natural protected and anthropogenically transformed areas, (2) analyzing official landslide reports and media to trace landslides in GE images, (3) identifying landslide source area and types, and (4) analyzing the resulted landslide inventory. Natural protected areas can be found in the upper slopes of high mountains, while anthropogenically transformed areas are all areas utilized by humans like built-up areas, agriculture, plantations, and induced vegetation (Dąbek et al., 2018; Figueroa \& Sánchez-Cordero, 2008). The following flowchart visualizes the steps in this study to create a landslide inventory by using GE (Figure 2).

\section{Result and Discussion}

Historical GE images from 1993 to 2020 were used to recognize landslides to produce polygon-based landslide inventory for Bandung Basin. One hundred ninety-four landslides were identified in natural protected areas and anthropogenic transformed areas (Table 1). Among those 194 landslides in Bandung Basin, the three largest landslides have a landslide area of more than $10 \mathrm{Ha}$, i.e., $15.97 \mathrm{Ha}, 15.57$ $\mathrm{Ha}$, and $10.8 \mathrm{Ha}$, respectively. The ten most significant landslides were presented in Table 1 and Figure 3. Four of the ten most considerable landslides are in anthropogenic transformed areas, i.e., No 3, 4, 6, and 8. Landslide No. 3 occurred at the Wayang Windu geothermal, while landslide 


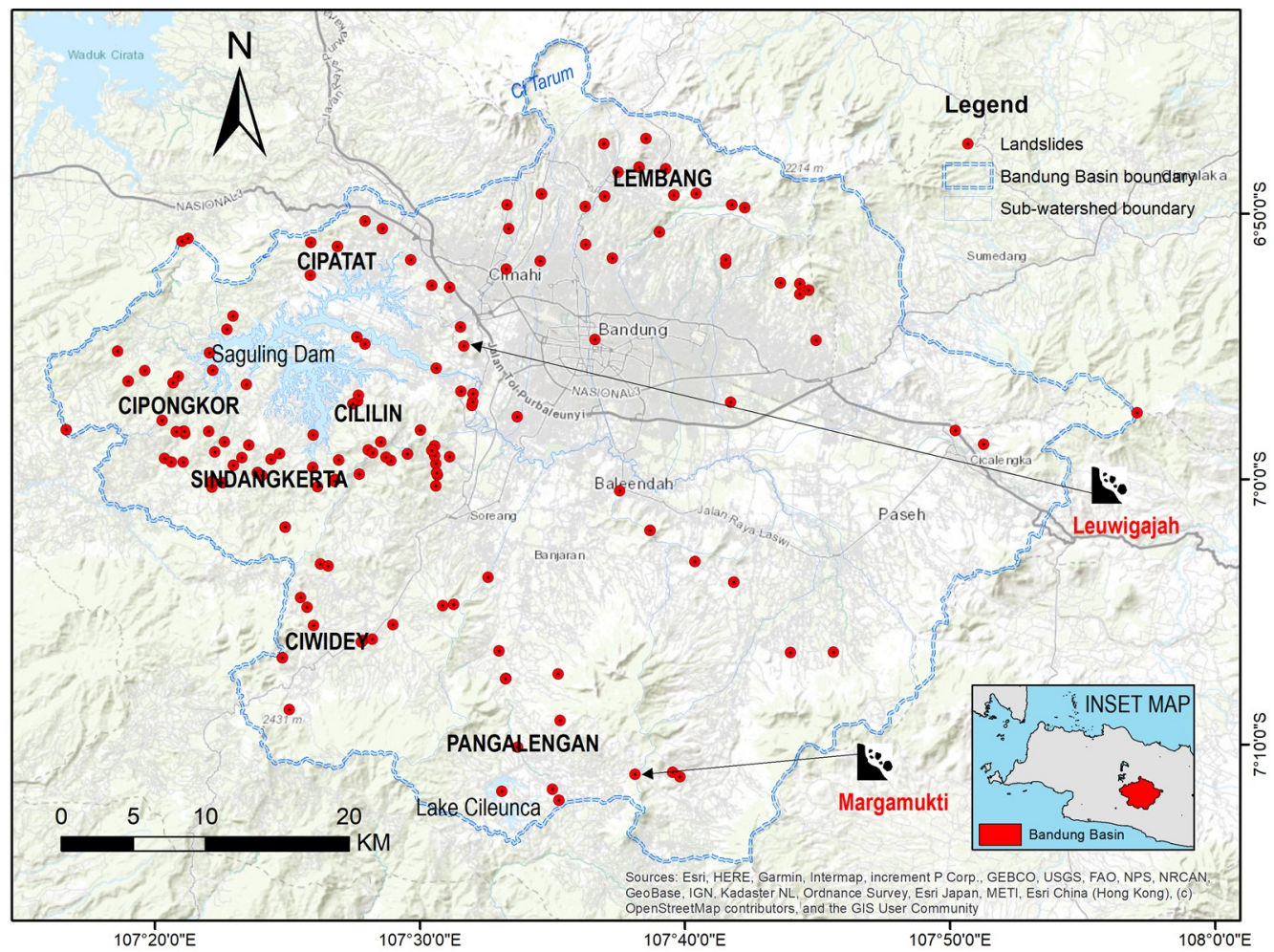

Figure 1. Landslide Distribution 2009-2020 and Two Devastating Landslides in The Study Area

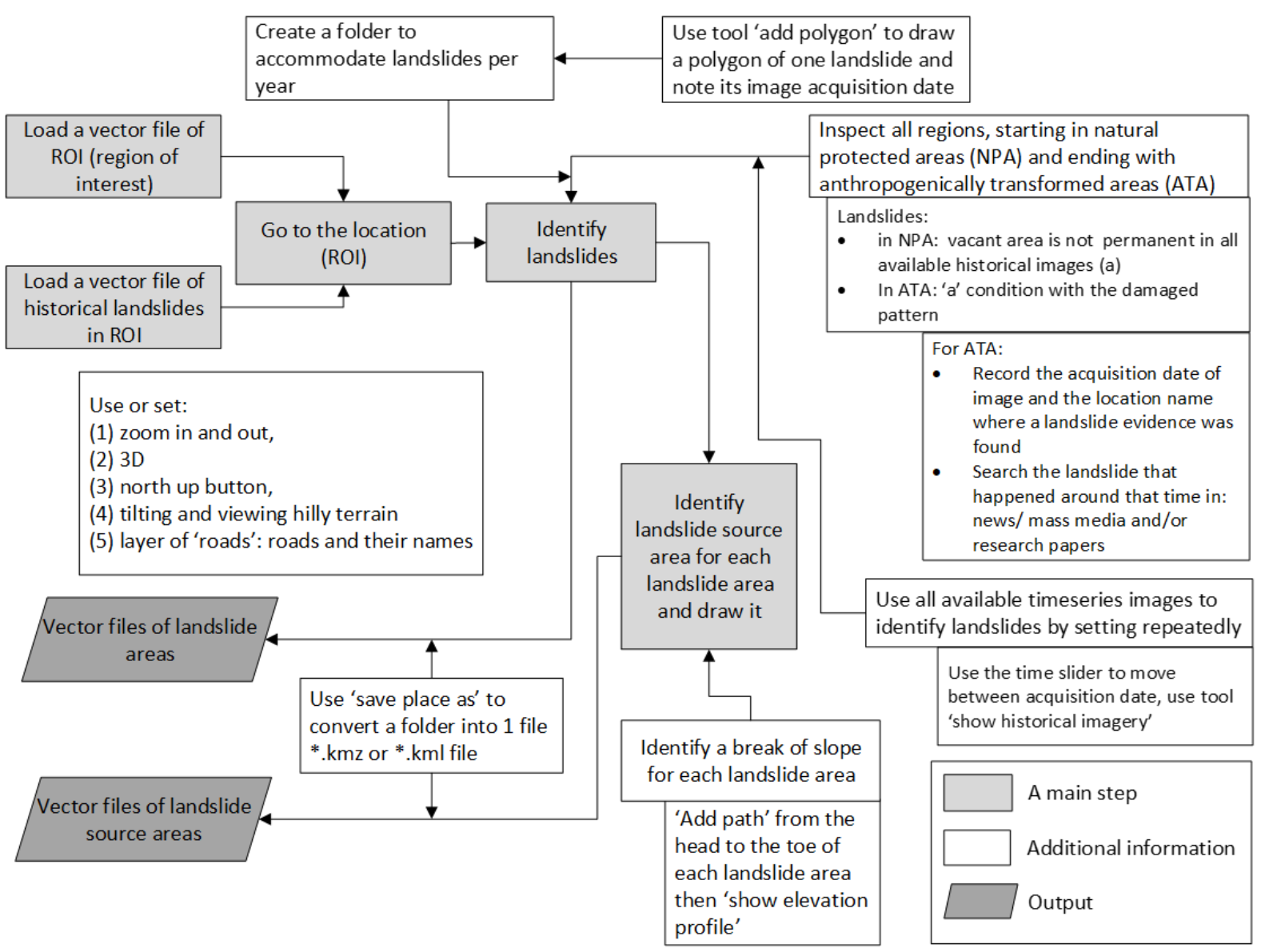

Figure 2. Flow chart of the research methods

No. 4 happened on the banks of the Cibintinu river, Arjasari Sub-district, dammed the river, which was feared to cause debris flow afterward and destroy several agricultural areas (Sukristiyanti, 2018). Landslide No. 6 occurred in the golf field, Cimenyan Sub-district, devastated a golf course. This caused worries for residents because the distance from the landslide is about $50 \mathrm{~m}$ only.

Landslides in the natural protected areas are more easily recognized in GE than in anthropogenically transformed ones. They are small vacant areas between the large vegetated 
Table 1. The ten most considerable landslides identified on Google Earth

\begin{tabular}{|c|c|c|c|c|c|}
\hline \multirow{2}{*}{$\begin{array}{l}\text { Area } \\
(\mathrm{Ha})\end{array}$} & \multirow{2}{*}{$\begin{array}{l}\text { Image acquisition } \\
\text { date }\end{array}$} & \multirow[b]{2}{*}{ Landuse } & \multicolumn{3}{|c|}{ Location } \\
\hline & & & Village & Sub-district & Regency \\
\hline 15.965 & 2 Oct 2018 & Forest & Genteng & Tanjungsari & Sumedang \\
\hline 15.574 & Dec 1993 & Forest & Sukarame & Pacet & Bandung \\
\hline 10.796 & 21 Mar 2017 & $\begin{array}{l}\text { Shrubs,settlement, } \\
\text { fishpond }\end{array}$ & Margamukti & Pangalengan & Bandung \\
\hline 4.535 & 12 May 2017 & Agriculture areas & Lebakwangi and Wargaluyu & Arjasari & Bandung \\
\hline 4.380 & 27 Sep 2013 & Forest & Cikawao & Pacet & Bandung \\
\hline 3.556 & 16 Aug 2016 & Grassland & Mekarsaluyu & Cimenyan & Bandung \\
\hline 2.934 & 31 Mar 2017 & Forest & Mekarsari & Pacet & Bandung \\
\hline 2.784 & 10 May 2018 & $\begin{array}{l}\text { Forest, agricultural } \\
\text { areas, settlement }\end{array}$ & Buninagara & Sindangkerta & West Bandung \\
\hline 2.631 & 28 Jun 2006 & Forest & Dukuh & Ibun & Bandung \\
\hline 1.817 & 27 Aug 2017 & Forest & Sukarame & Pacet & Bandung \\
\hline
\end{tabular}

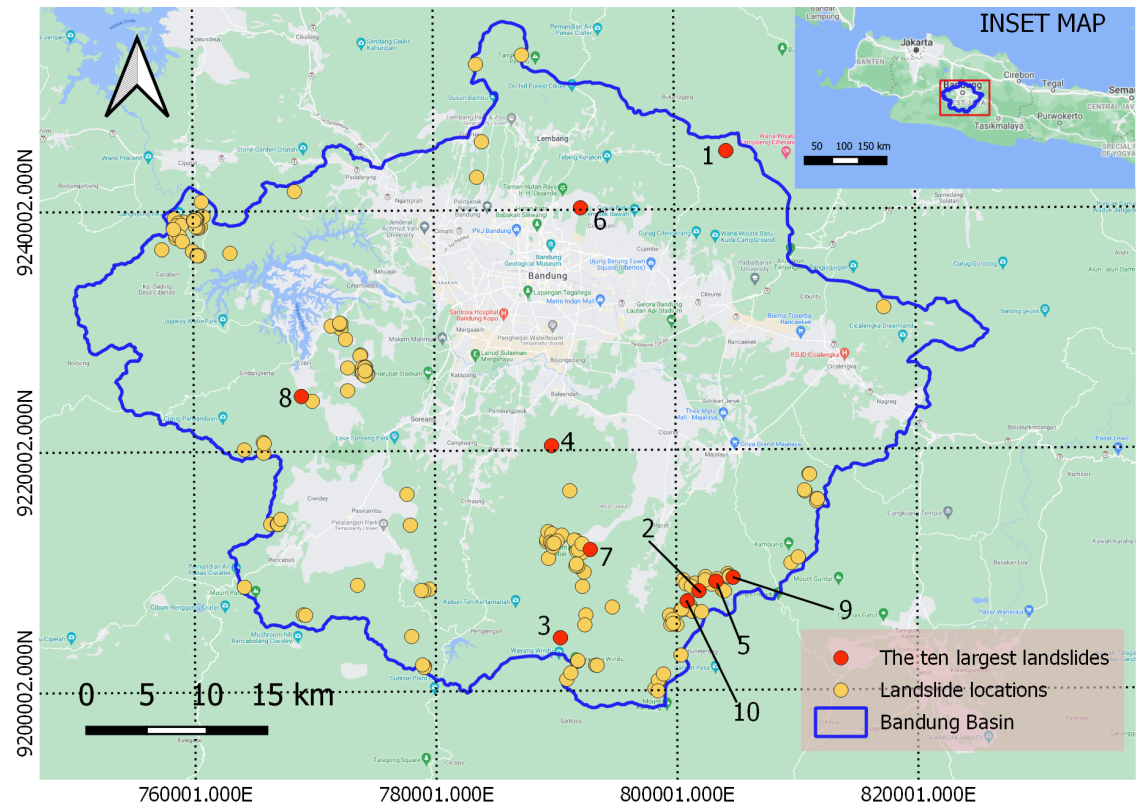

Figure 3. Landslide inventory map based on visual interpretation using Google Earth

areas or forests. The smallest object detected as a landslide in this study is about 39 square meters; it is influenced by the resolution of the images in Google Earth. The minor landslide can be detected by using more detailed images. The vacant areas are found in one or some images and absent in other previous or afterward images. If the vacant area is permanent in all available historical images, it is better not to assign the areas as landslides. To help consider whether the bare land is a landslide, it needs to set the position of those images. For instance, those images are directed so that it displays the landslide direction from top to bottom. In addition, setting the direction and terrain and using elevation profiles for specific paths are very helpful in landslide identification.

Identifying landslides in the anthropogenically transformed areas is rather tricky. It needs geospatial information, which can be obtained from official landslide reports or field surveys. The information is used to trace the exact location and boundary of a landslide. Three large landslides could be delineated in GE, i.e., landslides of numbers 3 , 4, and 6 (Table 1). A landslide on the roadside slope in Sugihmukti Village, Pasirjambu Sub-district, recorded in the official landslide data, was the smallest traceable landslide in the transformed area. The extent of the landslide area was $87.72 \mathrm{~m}^{2}$.

Without any guidance of geospatial information, landslides in the anthropogenically transformed can also be identified, for instance, landslides in agricultural areas. It can be recognized by finding a vacant area with the damaged pattern of rice field, changing the plant cover. A landslide was identified in an image of Jan, 2014, located in Warnasari Village, Pangalengan Sub-district. It can be seen in Figure 4 that the pattern of rice fields and dry land in the landslide area turned patternless. The landslide area is quite large, which is 5395 square meters. It is almost impossible if humans did the damage because the location is far from the roads, which is difficult for heavy equipment to reach.

Some supporting data such as the previous research papers, official landslide reports, and news were used to convince or give a clue of the presence of a landslide event. For instance, when landslide evidence was found in a specific image, the location and time of the image can be traced via 


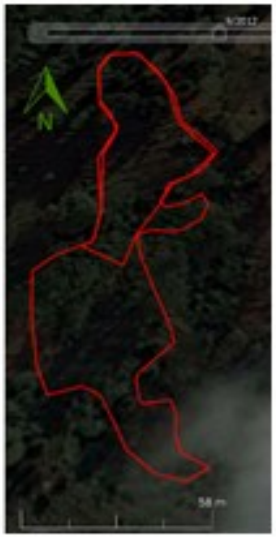

(a)

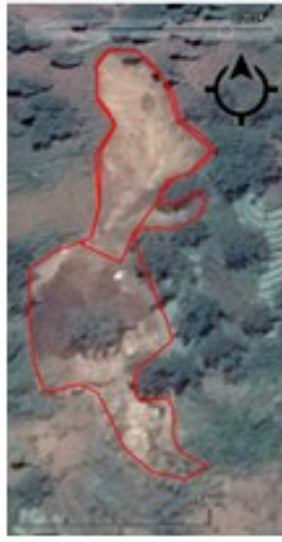

(b)

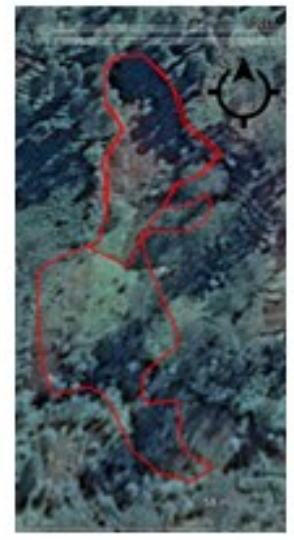

(c)

Figure 4. The changing of rice field and dry land patterns pre and post images of landslide: (a) pre landslide (Sept 2012), (b) landslide (Jan 2014), and (c) post landslide (July 2017)

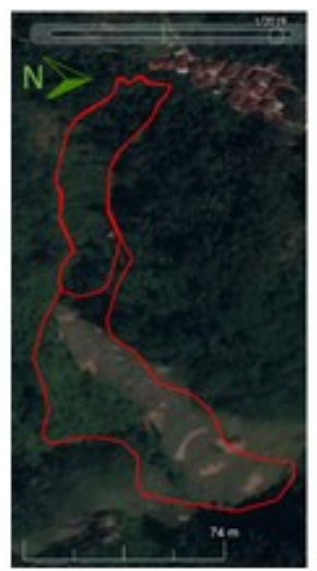

(a)

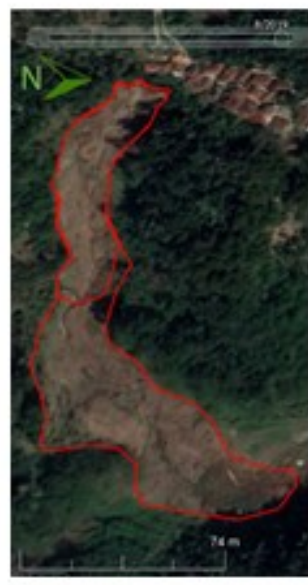

(b)

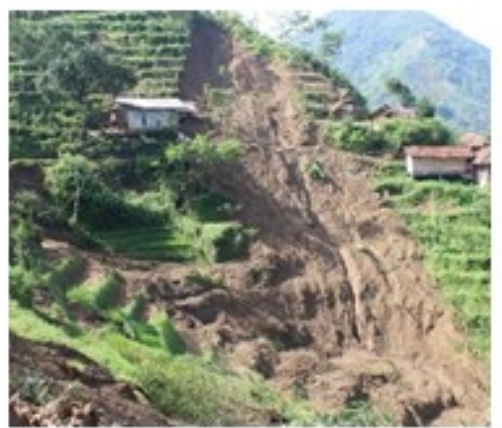

(c)

Figure 5. A landslide in Cicapeu of Kidangpananjung Village, Cililin Sub-district was confirmed in media: (a) pre landslide in GE, (b) post landslide in GE, (c) photograph of the landslide in the media

the internet. The time tends to be flexible because the date of the landslide is not necessarily the same as the date of the image. Substantial landslide evidence was found in Kidangpananjung Village, Cililin Sub-district in an image of August, 2019, and the landslide was confirmed by the news, obtained through the internet browsing (Figure 5). The news reported that landslides occurred in some locations in the village simultaneously because of heavy rain. Those landslides happened on May 13, 2019 (news.detik.com, May $15,2019)$, recorded around three months after the incident. In that case, eleven landslide locations were recognized in GE. The smallest area of landslide identified in the image is $75.7 \mathrm{~m}^{2}$. Some instances of landslides occurrences that were assisted by such supporting data in landslide identification on Google Earth are presented in Table 2.

The appearance of landslides in GE images is irregular (Rabby \& Li, 2019). In the previous images (Figure 4 -Figure $5)$, some landslide shapes were already presented. The illustrations can expand knowledge to ease in identifying
Table 2.The availability of supporting data in landslide inventory

\begin{tabular}{lcccc}
\hline Landslide & \multicolumn{4}{c}{ Supporting data } \\
\cline { 2 - 5 } location & $\begin{array}{c}\text { Research } \\
\text { paper }\end{array}$ & $\begin{array}{c}\text { Land- } \\
\text { slide } \\
\text { report }\end{array}$ & $\begin{array}{c}\text { Field } \\
\text { survey }\end{array}$ & News \\
\hline $\begin{array}{l}\text { Kidangpananjung, } \\
\text { Cililin }\end{array}$ & - & - & - & $\mathrm{V}$ \\
Roadside slope in & - & $\mathrm{v}$ & - & - \\
$\begin{array}{l}\text { Sugihmukti } \\
\text { Wayang Windu }\end{array}$ & $\mathrm{V}$ & $\mathrm{v}$ & $\mathrm{v}$ & $\mathrm{v}$ \\
Cibintinu River & $\mathrm{v}$ & $\mathrm{V}$ & $\mathrm{v}$ & $\mathrm{v}$ \\
Golf field & - & - & $\mathrm{v}$ & $\mathrm{v}$ \\
\hline
\end{tabular}

landslides in GE images. Irregular shapes are formed by natural processes (Rabby \& Li, 2019), influenced by many factors, e.g., slope, lithology, the driving force, the presence of rock and some landcover, etc. If there is a more robust 


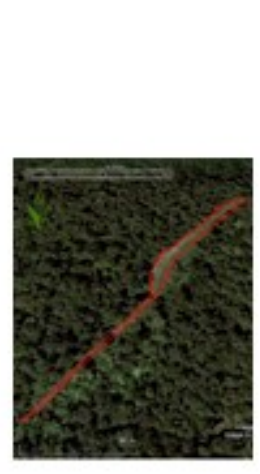

a

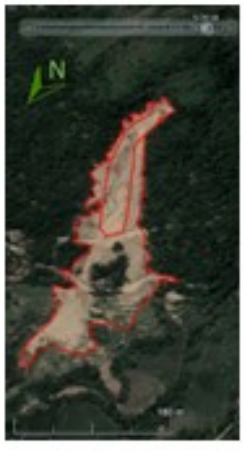

b

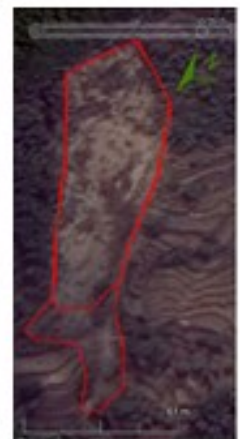

c

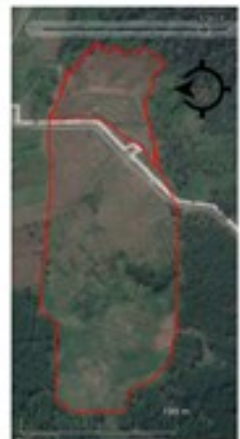

d

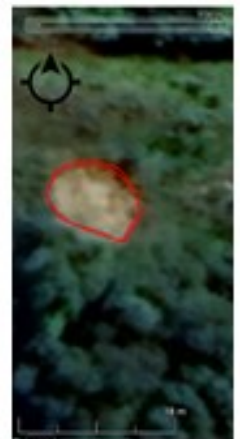

e

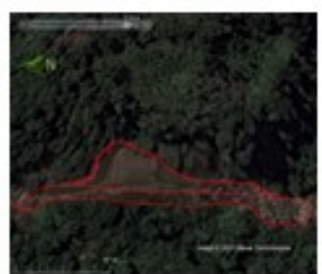

f

Figure 6. Some appearances of landslides in GE images: (a, b, c, d) elongated shapes of landslide and (e, f) wide or rounded shapes of landslide

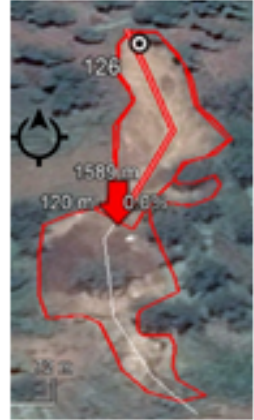

(a)

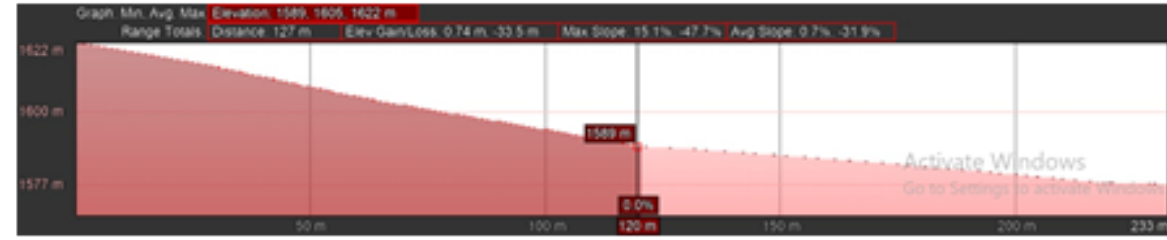

(b)

Figure 7. Position of break of slope: (a) in an image (red arrow), (b) in the elevation profile

material (rocks, trees, buildings) blocking and defeating the force of the landslide, the direction of the landslide will change (Ma et al., 2020; Naryanto, 2017; Sadisun et al., 2019). The shapes of landslides can be elongated and rounded generally (Samia et al., 2017) (Figure 6). Most landslides in Bandung Basin are long shapes resulting from landslides with a material displacement distance more remarkable than the width (NiculițĂ, 2016). A wide landslide was occurred in the riverbank in Rajamandala Village, Cipatat Sub-district, West Bandung Regency (Figure 6f). This condition is in line with the statement that round landslides most frequently happen along river banks and gully (Niculiț̆ă, 2016).

In addition to the landslide area boundary, the landslide source boundary can also be identified in GE. Although the satellite images in GE were not recorded immediately after the landslide, the landslide boundary could be recognized using multiple time-series images. The landslide source area may be a small, half, or a large part of the landslide area or the same as the landslide area. This condition is related to landslide conditions. The landslide polygons in Figure 4-8 do not represent landslide areas only, but also landslide source areas. The landslide source area represents a failure slope, a location that experiences movement (Hungr et al., 2014). Regarding the process, landslides consist of deformations of pre-failure, failure itself, and displacements of post-failure. The most significant movement is a failure (Hungr et al., 2014). Landslide area and landslide source area result in different accuracy for landslide susceptibility mapping. The landslide source area resulted in the highest accuracy for landslide susceptibility mapping on a scale of 1:10.000 (Schlögel et al., 2018). It means preparing landslide source area as landslide inventory data; instead, landslide area may increase the accuracy of landslide susceptibility map. The determination of landslide source boundary in GE is somewhat subjective because only a single DEM is available; thus, elevation profile pre and post landslide change could not be obtained. However, the landslide source area is still better than the whole landslide area to represent the failure slope in landslide susceptibility modeling (van Westen et al., 2008).

It has been mentioned that the landslide source area in some cases has the same boundary as the whole landslide area. If a landslide is on an upright slope where landslide material has fallen, its deposition area is not identified. This condition can also occur if a landslide is in a forest with very dense vegetation in which its deposition area could not be detected (Figure 6e). If there is a break of slope, a change of slope angle from steep into gentler, it may be a boundary of the landslide source. The slope break is familiar with debris flow, including landslide source, flow tracking, and depositional area. In a type of slide, the break of the slope is also frequently found. Figure 7 shows the break of slope both in the image and in the elevation profile to identify the boundary of the landslide source area. 


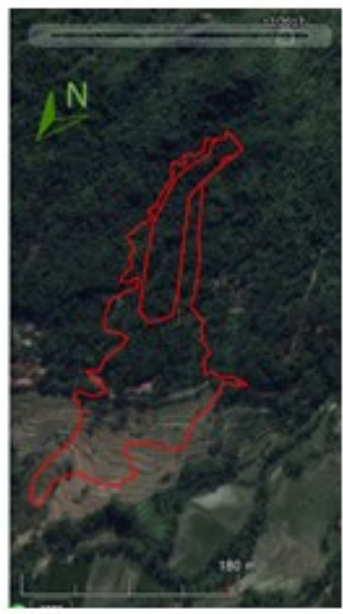

(a)

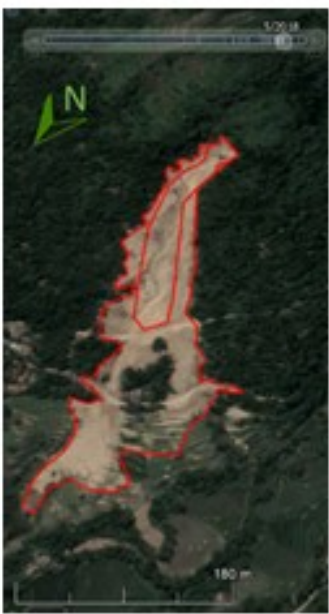

(b)

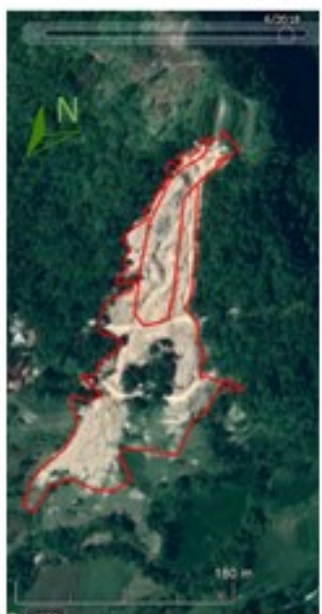

(c)

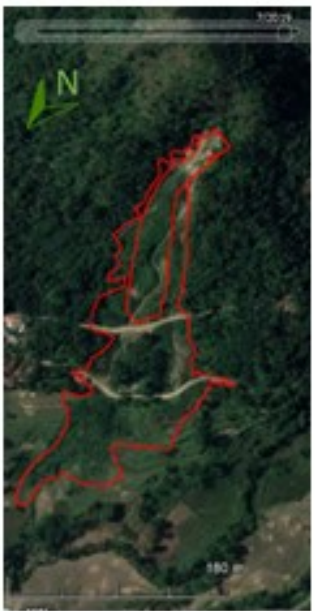

(d)

Figure 8 .The sequence of land-use changes in some historical GE images (before and after landslide event): (a) December 2017, (b) May 2018, (c) June 2018, (d) July 2019

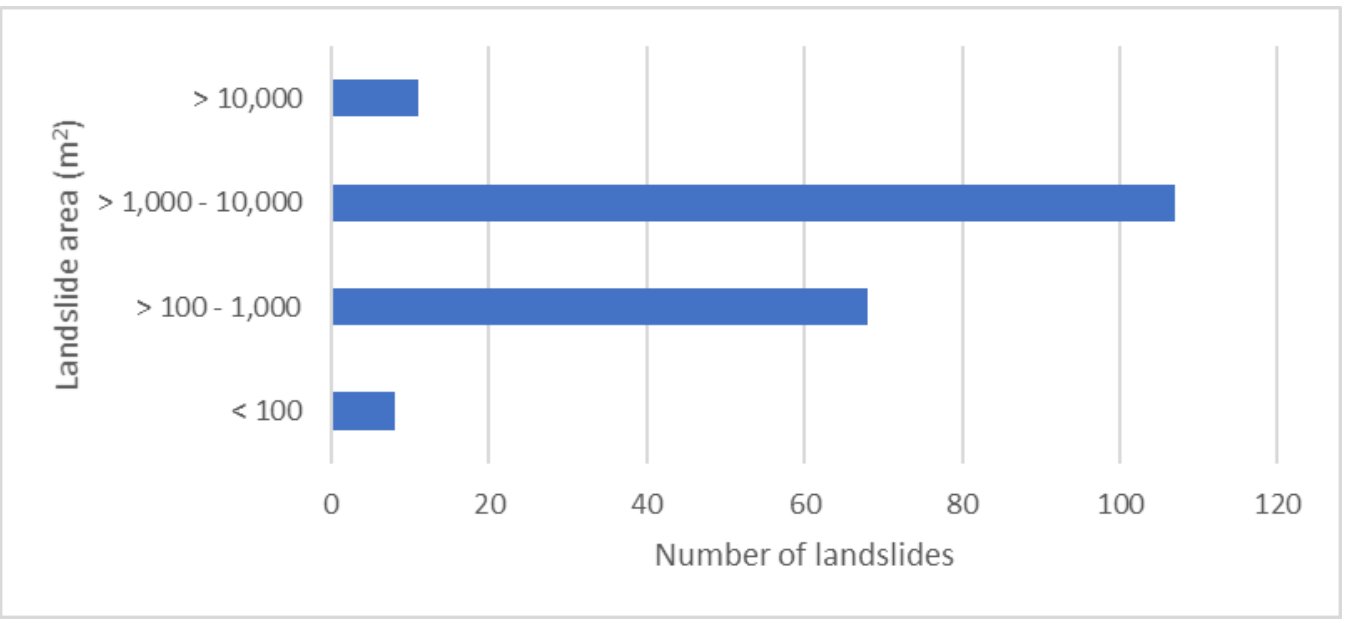

Figure 9. Chart of landslide areas $\left(\mathrm{m}^{2}\right)$ versus landslide number

Indonesia, as a tropical region, has rapid vegetation growth. This condition makes it an obstacle to recognize landslide evidence using an image if the image is not acquired just after the incident (Samodra et al., 2017). The worse, timeseries GE images do not continue; the time interval between images is uncertain (Rabby \& $\mathrm{Li}, 2019$ ). In one place of a particular time, the available time-series images can be abundant; but the times-series images can be infrequent in other sites or other times. By comparing the change of old landslide appearance in some historical GE images, it can be observed how long a landslide is covered by vegetation. An example observation performed in a landslide occurred in Bonjot Sub-village, Buninagara Village, Sindangkerta Subdistrict on March 5, 2018 (jabar.tribunnews.com, March 5, 2018). Evidence of landslides was found on GE images from 10 May 2018 to 19 June 2018, and the old landslide was covered with vegetation within two months, i.e., 21 July 2018 (Figure 8).

Referring to the working party of the International Geotechnical Inventory of UNESCO, landslides based on the material type are classified into three types, i.e., rock, debris, and earth (Sassa, 2007). In this study, a landslide with rock material was not found, only debris or earth which can be found. Debris is dominated by coarse soils, while the earth is dominated by fine soils (Sassa, 2007). Between them, debris and earth were indistinguishable in this study.

The landslides are classified into fall, topple, slide, spread, and flow (Sassa, 2007). Regarding this landslide inventory carried out, the landslide types of fall, slide, and flow can be recognized, but not to topple and spread. Creep, a very slow landslide, could not be identified by GE. Geospatial information of many creeps from official landslide reports is already plotted in GE, but none can be traced. Creep is included in the flow type of landslide; its shear stress can cause permanent deformation but could not cause shear failure (USGS, 2004).

The area of landslides in Bandung Basin varies from 39.13 $\mathrm{m}^{2}$ to $159,654.24 \mathrm{~m}^{2}(15.97 \mathrm{Ha})$, with a total landslide of 99.13 Ha. To figure out the dominance of area of landslides happened in Bandung Basin, the range of landslide area were 
classified into four classes, i.e. $(1)<100 \mathrm{~m}^{2},(2)>100-1000$ $\mathrm{m}^{2},(3)>1000-10000 \mathrm{~m}^{2}$, and (4) > $10000 \mathrm{~m}^{2}$ (Figure 9). It can be seen that large landslides, landslides with an area of more than $10000 \mathrm{~m}^{2}(1 \mathrm{Ha})$, have occurred eleven (11) times in this research area. Only a small number of small landslides have been identified with GE. This condition does not mean that small landslides rarely occur in this area, but rather because of the limited availability of time-series imageries and the limited spatial resolution of GE images.

Seventy landslides have occurred in only one village in Bandung Basin, i.e., Weninggalih Village, Sindangkerta Subdistrict, West Bandung District obtained by field investigation (Sadisun et al., 2006). Those landslides were dominated by small dimensions with a size less than $10 \mathrm{~m}$ in length and width. It means that many other small landslides in Bandung Basin could not be recognized using GE. A field survey is conducted as an alternative effort to improve the landslide inventory derived from GE. It is mainly conducted along roads and in urban (Rabby \& $\mathrm{Li}, 2019$ ). Therefore, it will be a complementary effort to fulfill the lack of GE capability in detecting landslide evidence.

Landslide reports or news and scientific writings only report or discuss landslides that directly or indirectly impact humans, e.g., fatalities and property damages, settlement and infrastructure demages, and economic activities disruptions . If a landslide has no impact at all, it is improbable to be investigated or reported. Therefore, landslides in remote areas could not be traced in the all supporting data. Only landslides with significant impacts are discussed the most, for example, the landslide in the Wayang Windu geothermal, which can be traced both in landslide reports, news, and previous research papers.

\section{Conclusion}

GE can produce polygon-based landslide inventories consisting of landslide areas and landslide source areas. The limitations of GE are (1) not covering the timing of the landslide occurrences, (2) tricky to identify small landslides $\left(<100 \mathrm{~m}^{2}\right)$ in anthropogenically transformed areas, and (3) not able to distinguish between earth and debris of landslide material. Intensive field surveys in anthropogenically transformed areas or the using of other high resolution imageries are strongly encouraged to fill data gaps in order to obtain an ideal landslide inventory.

\section{Acknowledgment}

This study is supported by Saintek-Kemenristek/BRIN Scholarship Program. The author would like to thank Research Centre for Geotechnology LIPI for facilitating this research. The author also wishes to thank the Centre for Volcanology and Geological Hazard Mitigation (PVMBG) for providing this research data. Thanks also go to Google Earth, Google Maps, and QGIS, which were used for free in this study.

\section{References}

Anbalagan, R. (1992). Landslide hazard evaluation and zonation mapping in mountainous terrain. Engineering Geology, 32(4), 269-277. https://doi.org/10.1016/0013-7952(92)90053-2

Cao, W., Tong, X. H., Liu, S. C., \& Wang, D. (2016). Landslides extraction from diverse remote sensing data sources using semantic reasoning scheme. International Archives of the Photogrammetry, Remote Sensing and Spatial Information Sciences - ISPRS Archives, 41(July), 25-31. https://
doi.org/10.5194/isprsarchives-XLI-B8-25-2016

Cepeda, J., Smebye, H., Vangelsten, B., Nadim, F., \& Muslim, D. (2010). Landslide risk in Indonesia. October, October, 20. http://www.preventionweb.net/english/hyogo/gar/2011/en/ bgdocs/Cepeda_et_al._2010.pdf

Chen, W., Pourghasemi, H. R., \& Naghibi, S. A. (2017). A comparative study of landslide susceptibility maps produced using support vector machine with different kernel functions and entropy data mining models in China. Bulletin of Engineering Geology and the Environment, 77(2), 647-664. https://doi.org/10.1007/s10064-017-1010-y

Dąbek, P. B., Patrzałek, C., Ćmielewski, B., \& Żmuda, R. (2018). The use of terrestrial laser scanning in monitoring and analyses of erosion phenomena in natural and anthropogenically transformed areas. Cogent Geoscience, 4(1), 1437684. https:// doi.org/10.1080/23312041.2018.1437684

Dou, J., Chang, K. T., Chen, S., Yunus, A. P., Liu, J. K., Xia, H., \& $\mathrm{Zhu}, \mathrm{Z}$. (2015). Automatic case-based reasoning approach for landslide detection: Integration of object-oriented image analysis and a genetic algorithm. Remote Sensing, 7(4), 43184342. https://doi.org/10.3390/rs70404318

Figueroa, F., \& Sánchez-Cordero, V. (2008). Effectiveness of natural protected areas to prevent land use and land cover change in Mexico. Biodiversity and Conservation, 17(13), 3223-3240. https://doi.org/10.1007/s10531-008-9423-3

Guzzetti, F., Carrara, A., Cardinali, M., \& Reichenbach, P. (1999) Landslide hazard evaluation: A review of current techniques and their application in a multi-scale study, Central Italy. Geomorphology, 31(1-4), 181-216. https://doi.org/10.1016/ S0169-555X(99)00078-1

Hong, H., Shahabi, H., Shirzadi, A., Chen, W., Chapi, K., Ahmad, B. Bin, Roodposhti, M. S., Yari Hesar, A., Tian, Y., \& Tien Bui, D. (2019). Landslide susceptibility assessment at the Wuning area, China: a comparison between multi-criteria decision making, bivariate statistical and machine learning methods. In Natural Hazards (Vol. 96, Issue 1). Springer Netherlands. https:// doi.org/10.1007/s11069-018-3536-0

Hungr, O., Leroueil, S., \& Picarelli, L. (2014). The Varnes classification of landslide types, an update. Landslides, 11(2), 167-194. https://doi.org/10.1007/s10346-013-0436-y

Juliev, M., Mergili, M., Mondal, I., Nurtaev, B., Pulatov, A., \& Hübl, J. (2019). Comparative analysis of statistical methods for landslide susceptibility mapping in the Bostanlik District, Uzbekistan. Science of the Total Environment, 653, 801-814. https://doi.org/10.1016/j.scitotenv.2018.10.431

Kalantar, B., Pradhan, B., Amir Naghibi, S., Motevalli, A., \& Mansor, S. (2018). Assessment of the effects of training data selection on the landslide susceptibility mapping: a comparison between support vector machine (SVM), logistic regression (LR) and artificial neural networks (ANN). Geomatics, Natural Hazards and Risk, 9(1), 49-69. https:// doi.org/10.1080/19475705.2017.1407368

Kartiko, R. D., Brahmantyo, B., \& I.A.Sadisun. (2006). Slope and Lithological Controls on Landslide Distribution in West. International Symposium on Geotechnical Hazards: Prevention, Mitigation and Engineering Response, Utomo, Tohari, Murdohardono, Sadisun, April 2006., April, 177-184 https://doi.org/10.13140/2.1.2208.5442

Kavzoglu, T., Colkesen, I., \& Sahin, E. K. (2019). Landslides: Theory, Practice and Modelling (S. P. Pradhan, V. Vishal, \& T. N. Singh (eds.); Vol. 50). https://doi.org/10.1007/978-3-31977377-3

Keyport, R. N., Oommen, T., Martha, T. R., Sajinkumar, K. S., \& Gierke, J. S. (2018). A comparative analysis of pixel- and objectbased detection of landslides from very high-resolution images. International Journal of Applied Earth Observation and Geoinformation, 64(September 2017), 1-11. https:// doi.org/10.1016/j.jag.2017.08.015

Lavigne, F., Wassmer, P., Gomez, C., Davies, T. A., Sri Hadmoko, D., Iskandarsyah, T. Y. W. M., Gaillard, J., Fort, M., Texier, P., Boun Heng, M., \& Pratomo, I. (2014). The 21 February 2005, 
catastrophic waste avalanche at Leuwigajah dumpsite, Bandung, Indonesia. Geoenvironmental Disasters, 1(1), 1-12. https:// doi.org/10.1186/s40677-014-0010-5

Lee, S., \& Talib, J. A. (2005). Probabilistic landslide susceptibility and factor effect analysis. Environmental Geology, 47(7), 982990. https://doi.org/10.1007/s00254-005-1228-Z

Li, Z., Shi, W., Myint, S. W., Lu, P., \& Wang, Q. (2016). Semiautomated landslide inventory mapping from bitemporal aerial photographs using change detection and level set method. Remote Sensing of Environment, 175(March), 215-230. https:// doi.org/10.1016/j.rse.2016.01.003

Liu, J., \& Duan, Z. (2018). Quantitative assessment of landslide susceptibility comparing statistical index, index of entropy, and weights of evidence in the Shangnan Area, China. Entropy, 20 (11), 9-11. https://doi.org/10.3390/e20110868

Ma, S., Xu, C., Xu, X., He, X., Qian, H., Jiao, Q., Gao, W., Yang, H., Cui, Y., Zhang, P., Li, K., Mo, H., Liu, J., \& Liu, X. (2020). Characteristics and causes of the landslide on July 23, 2019 in Shuicheng, Guizhou Province, China. Landslides, 17(6), 14411452. https://doi.org/10.1007/s10346-020-01374-x

Mallick, J., Singh, R. K., AlAwadh, M. A., Islam, S., Khan, R. A., \& Qureshi, M. N. (2018). GIS-based landslide susceptibility evaluation using fuzzy-AHP multi-criteria decision-making techniques in the Abha Watershed, Saudi Arabia. Environmental Earth Sciences, 77(7), 1-25. https:// doi.org/10.1007/s12665-018-7451-1

Marjanovic, M. (2013). Advanced methods for landslide assessment using GIS [Palacký University Olomouc]. https://theses.cz/id/ erd35p/00182008-728806523.pdf

Moosavi, V., Talebi, A., \& Shirmohammadi, B. (2014). Producing a landslide inventory map using pixel-based and object-oriented approaches optimized by Taguchi method. Geomorphology, 204, 646-656. https://doi.org/10.1016/j.geomorph.2013.09.012

Mora, S., \& Vahrson, W.-G. (1994). Macrozonation Methodology for Landslide Hazard Determination. Environmental \& Engineering Geoscience, $x x x i(1), \quad 49-58 . \quad$ https:// doi.org/10.2113/gseegeosci.xxxi.1.49

Naryanto, H. S. (2017). Analisis Kejadian Bencana Tanah Longsor Tanggal 12 Desember 2014 Di Dusun Jemblung, Desa Sampang, Kecamatan Karangkobar, Kabupaten Banjarnegara, Provinsi Jawa Tengah. Jurnal Alami: Jurnal Teknologi Reduksi Risiko Bencana, 1(1), 1. https://doi.org/10.29122/alami.vli1.122

Niculiță, M. (2016). Automatic landslide length and width estimation based on the geometric processing of the bounding box and the geomorphometric analysis of DEMs. Natural Hazards and Earth System Sciences, 16(8), 2021-2030. https:// doi.org/10.5194/nhess-16-2021-2016

Othman, A. A., Gloaguen, R., Andreani, L., \& Rahnama, M. (2018). Improving landslide susceptibility mapping using morphometric features in the Mawat area, Kurdistan Region, NE Iraq: Comparison of different statistical models. Geomorphology, 319, 147-160. https://doi.org/10.1016/ j.geomorph.2018.07.018

Pham, B. T., Jaafari, A., Prakash, I., \& Bui, D. T. (2018). A novel hybrid intelligent model of support vector machines and the MultiBoost ensemble for landslide susceptibility modeling. Bulletin of Engineering Geology and the Environment, 78(4), 2865-2886. https://doi.org/10.1007/s10064-018-1281-y

Rabby, Y. W., \& Li, Y. (2019). An integrated approach to map landslides in Chittagong Hilly Areas, Bangladesh, using Google Earth and field mapping. Landslides, 16(3), 633-645. https:// doi.org/10.1007/s10346-018-1107-9

Rahardjo, P. P., Hosoda, T., \& Handoko, A. (2017). Investigation of Landslides and Monitoring of The Subsequent Ground Movement and Geothermal New Pipe Lines Foundation in West Java. $F$ the 19th International Conference on Soil Mechanics and Geotechnical Engineering, 635-638. https:// www.issmge.org/uploads/publications/1/45/06-technicalcommittee-02-tc102-20.pdf

Riaz, M. T., Basharat, M., Hameed, N., Shafique, M., \& Luo, J. (2018). A Data-Driven Approach to Landslide-Susceptibility
Mapping in Mountainous Terrain: Case Study from the Northwest Himalayas, Pakistan. Natural Hazards Review, 19(4), 05018007. https://doi.org/10.1061/(asce)nh.1527-6996.0000302

Roccati, A., Paliaga, G., Luino, F., Faccini, F., \& Turconi, L. (2021). Planning and Risk Assessment.

Roslee, R., Jamaludin, T. A., \& Simon, N. (2017). Landslide Vulnerability Assessment (LVAs): A case study from Kota Kinabalu, Sabah, Malaysia. Indonesian Journal on Geoscience, 4(1), 49-59. https://doi.org/10.17014/ijog.4.1.49-59

Sadisun, I. A., Kartiko, R. D., \& Adianto, A. Y. (2006). Landslide Frequency Analysis in a Mountainous Area of Weninggalih , West Java , Indonesia - a Technical Note. PROCEEDINGS PIT IAGI RIAU 2006. The 35th IAGI Annual Convention and Exhibition, November, 21-22. https:// doi.org/10.13140/2.1.3584.0322

Sadisun, I. A., Kartiko, R. D., \& Dinata, I. A. (2019). Pengamatan Lapangan Aliran Bahan Rombakan di Sirnaresmi, Kabupaten Sukabumi. https://doi.org/10.31227/osf.io/m4pg3

Samia, J., Temme, A., Bregt, A., Wallinga, J., Guzzetti, F., Ardizzone, F., \& Rossi, M. (2017). Do landslides follow landslides? Insights in path dependency from a multi-temporal landslide inventory. Landslides, 14(2), 547-558. https:// doi.org/10.1007/s10346-016-0739-x

Samodra, G., Chen, G., Sartohadi, J., \& Kasama, K. (2017). Comparing data-driven landslide susceptibility models based on participatory landslide inventory mapping in Purwosari area, Yogyakarta, Java. Environmental Earth Sciences, 76(4), 119. https://doi.org/10.1007/s12665-017-6475-2

Sassa, K. (2007). Landslide science as a new scientific discipline. Progress in Landslide Science, 1978, 3-11. https:// doi.org/10.1007/978-3-540-70965-7_1

Schlögel, R., Marchesini, I., Alvioli, M., Reichenbach, P., Rossi, M., \& Malet, J. P. (2018). Optimizing landslide susceptibility zonation: Effects of DEM spatial resolution and slope unit delineation on logistic regression models. Geomorphology, 301, 10-20. https://doi.org/10.1016/j.geomorph.2017.10.018

Shirani, K., Pasandi, M., \& Arabameri, A. (2018). Landslide susceptibility assessment by Dempster-Shafer and Index of Entropy models, Sarkhoun basin, Southwestern Iran. Natural Hazards, 93(3), 1379-1418. https://doi.org/10.1007/s11069-018 $-3356-2$

Sukristiyanti, S. (2018). Analisis Morfometri Das Di Daerah Rentan Gerakan Tanah. Seminar Nasional Geomatika, 2(April), 307. https://doi.org/10.24895/sng.2017.2-0.425

Tian, Y., Xu, C., Hong, H., Zhou, Q., \& Wang, D. (2019). Mapping earthquake-triggered landslide susceptibility by use of artificial neural network (ANN) models: an example of the 2013 Minxian (China) Mw 5.9 event. Geomatics, Natural Hazards and Risk, 10(1), 1-25. https:// doi.org/10.1080/19475705.2018.1487471

Tukino, T. (2021). Implementation of Cognitive Behavioral Therapy (Cbt) for the Elderly in Reducing Anxiety Due To Landslides in Margamukti Village-Bandung Regency. Indonesian Journal of Social Work, 4(02). https:// doi.org/10.31595/ijsw.v4i02.337

USGS. (2004). Landslide Types and Processes. In Fact Sheet 20043072. https://pubs.usgs.gov/fs/2004/3072/fs-2004-3072.html

van Westen, C. J., Castellanos, E., \& Kuriakose, S. L. (2008). Spatial data for landslide susceptibility, hazard, and vulnerability assessment: An overview. Engineering Geology, 102(3-4), 112131. https://doi.org/10.1016/j.enggeo.2008.03.010

van Westen, C. J., van Asch, T. W. J., \& Soeters, R. (2006). Landslide hazard and risk zonation - Why is it still so difficult? Bulletin of Engineering Geology and the Environment, 65(2), 167-184. https://doi.org/10.1007/s10064-005-0023-0

Wang, D., Hao, M., Chen, S., Meng, Z., Jiang, D., \& Ding, F. (2021). Assessment of landslide susceptibility and risk factors in China. Natural Hazards, 0123456789. https://doi.org/10.1007/s11069021-04812-8

$\mathrm{Xu}$, C. (2015). Preparation of earthquake-triggered landslide inventory maps using remote sensing and GIS technologies: 
Principles and case studies. Geoscience Frontiers, 6(6), 825-836. https://doi.org/10.1016/j.gsf.2014.03.004

Yu, B., \& Chen, F. (2017). A new technique for landslide mapping from a large-scale remote sensed image: A case study of Central Nepal. Computers and Geosciences, 100(December 2016), 115124. https://doi.org/10.1016/j.cageo.2016.12.007

Yuhendar, A. H., Wusqa, U., Kartiko, R. D., Raya, N. R., \& Misbahudin. (2016). Slope stability analysis of landslide in Wayang Windu Geothermal Field, Pangalengan, West Java Province, Indonesia. AIP Conference Proceedings, 1730 (November). https://doi.org/10.1063/1.4947412

Zhang, T., Han, L., Han, J., Li, X., Zhang, H., \& Wang, H. (2019). Assessment of landslide susceptibility using integrated ensemble fractal dimension with Kernel logistic regression model. Entropy, 21(2). https://doi.org/10.3390/e21020218

Zhu, A. X., Miao, Y., Yang, L., Bai, S., Liu, J., \& Hong, H. (2018). Comparison of the presence-only method and presence-absence method in landslide susceptibility mapping. Catena, 171 (March), 222-233. https://doi.org/10.1016/j.catena.2018.07.012

\section{Websites}

'Foto-foto-bencana-longsor-di-gunung-bonjot-dua-tewastertimbun', jabar.tribunnews.com, 5 March 2018. https:// jabar.tribunnews.com/2018/03/05/foto-foto-bencana-longsor-di -gunung-bonjot-dua-tewas-tertimbun

'Warga Terdampak Longsor Cililin Keluhkan Minim Air Bersihnews'. detik.com, 15 May 2019. news.detik.com/beritajawa-barat/d-4550422/warga-terdampak-longsor-cililinkeluhkan-minim-air-bersih

'Berita Gerakan Tanah', https://vsi.esdm.go.id/index.php/gerakantanah/kejadian-gerakan-tanah 